\title{
EVALUASI IMPLEMENTASI KURIKULUM 2013 PADA SMA PILOT PROJECT
} DI KOTA YOGYAKARTA

\author{
Utami Nurul Hasanah \\ Balai Pemuda Olahraga Yogyakarta \\ utami89jog@gmail.com
}

\begin{abstract}
Abstrak
Penelitian ini bertujuan mengevaluasi keefektifan dan mengetahui hambatan yang dihadapi dalam implementasi Kurikulum 2013 pada SMA pilot project di Kota Yogyakarta. Penelitian ini adalah penelitian evaluasi menggunakan model Discrepancy Provus dengan sasaran guru. Instrumen pengumpul data berupa angket dengan jawaban skala 2 (Guttman). Validitas instrumen berupa validitas logis dan empiris dihitung dengan Pearson product moment. Reliabilitasnya dihitung dengan teknik Kuder-Richardson (KR20). Teknik analisis data adalah teknik persentase. Hasil penelitian ini adalah (1) keefektifan evaluasi implementasi Kurikulum 2013 di SMA pilot project Kota Yogyakarta adalah 87,44\% dengan rata-rata kesenjangan (discrepancy) $12,56 \%$ dengan standar deviasi 8,98\%. Capaian tersebut menunjukkan kriteria efektif; (2) hambatan yang paling sedikit dilakukan guru adalah kurangnya dukungan implementator lain yaitu pustakawan memiliki rata-rata capaian tertinggi $85,50 \%$ dengan rata-rata kesenjangan (discrepancy) 14,50\%. Hambatan terbesar adalah guru dihadapkan pada masalah peserta didik yang komplek dengan segala latar belakang kognitif maupun kepribadian yaitu $46,00 \%$ dengan rata-rata kesenjangan (discrepancy) 54,00\%.
\end{abstract}

Kata kunci: implementasi Kurikulum 2013, evaluasi

\section{AN EVALUATION OF THE IMPLEMENTATION OF CURRICULUM 2013 AT PILOT PROJECT SENIOR HIGH SCHOOL IN YOGYAKARTA MUNICIPALITY}

\author{
Utami Nurul Hasanah \\ Balai Pemuda Olahraga Yogyakarta \\ utami89jog@gmail.com
}

\begin{abstract}
This research aims to evaluate the effectiveness and find out the obstacles encountered in the implementation of Curriculum 2013 at the pilot project senior high school in Yogyakarta. This research is an evaluation study using the models Discrepancy Provus with teachers as the target. The data were collected using a questionnaire with response two-scale response (Guttman scale). The validity of the instrument included logical and the empirical validity calculated with Pearson product moment. The reliability was measured using the Kuder-Richardson (KR20) technique. The data were analyzed using the percentage technique. The results of this study indicate that: (1) the average achievement evaluation of the implementation of Curriculum 2013 in the Yogyakarta City High School pilot project was $87,44 \%$ with an average gap (discrepancy) $12,56 \%$ with a standard deviation of 8,98 which shows the criteria of "Effective"; (2) the least barries is the lack of support from other implementers that is librarians who have on average the highest achievement that is $85.50 \%$ with an average gap (discrepancies) 14,50\%. Meanwhile, the biggest obstacle is the teacher faced with a complex problem that is, learners with all the background of cognitive and personality as much as $46,00 \%$ with an average gap (discrepancy) $54,00 \%$.
\end{abstract}

Keywords: implementation of Curriculum 2013, evaluation 


\section{Pendahuluan}

Persaingan global mengakibatkan pendidikan nasional dihadapkan pada permasalahan yang tidak linear antara pendidikan dan kenyataan di dunia kerja. Perkembangan dunia kerja tidak dapat lagi terkejar oleh mutu pendidikan di Indonesia. Dalam rangka mempersiapkan lulusan pendidikan memasuki era globalisasi yang penuh tantangan dan ketidakpastian, diperlukan pendidikan yang dirancang berdasarkan kebutuhan nyata di lapangan. Untuk kepentingan tersebut pemerintah melalui Departemen Pendidikan Nasional (Depdiknas) memprogramkan dan mengupayakan perbaikan, pembaharuan, dan penyempurnaan kurikulum pendidikan Indonesia. Upaya konkrit tersebut yaitu dengan melakukan langkah perbaikan kurikulum yang berlaku pada tahun ajaran sebelumnya yaitu Kurikulum Tingkat Satuan Pendidikan (KTSP) dengan Kurikulum 2013 sebagai acuan dalam pendidikan di sekolah.

Kurikulum 2013 dapat diartikan sebagai suatu konsep kurikulum yang menekankan kepada pengembangan kompetensi secara terpadu yaitu kompetensi sikap, pengetahuan, dan ketrampilan. Kurikulum 2013 dikembangkan dengan tujuan memperbaiki kelemahan pada kurikulum sebelumnya yaitu KBK 2004 dan KTSP 2006 yang menitikberatkan pada kompetensikompetensi potensial siswa yang bervariasi. Atas dasar tersebut, Kurikulum 2013 ini dianggap dapat memecahkan masalah kekurangberhasilan pendidikan Indonesia dengan membekali siswa dengan berbagai kemampuan yang sesuai dengan tantangan global, berkontribusi pada pembangunan masyarakat dan kesejahteraan sosial, lentur, dan adaptif terhadap perubahan.

Kebijakan awal pemerintah untuk mempersiapkan penerapan Kurikulum 2013 adalah dengan menerapkan secara bertahap mulai tahun ajaran 2013/2014 pada beberapa sekolah yang memenuhi kriteria sebagai pilot project penyelenggara Kurikulum 2013. Kurikulum 2013 yang diwacanakan pemerintah mulai tahun ajaran 2013/2014 melalui tahap awal yaitu mini piloting di beberapa sekolah termasuk di tingkat Sekolah Menengah Atas (SMA) Kota Yogyakarta. Mini piloting merupakan salah satu upaya sosialisasi dan tahap awal penerapan Kurikulum 2013.

Kesiapan sekolah sebagai penyelenggara pendidikan dalam mewujudkan keberhasilan implementasi Kurikulum 2013 seperti yang dilakukan oleh sekolah pilot project diharapkan dapat menjadi tolak ukur bagi sekolah lain atau menjadi sekolah percontohan Kurikulum 2013. Namun pada kenyataannya, tidak semua sekolah siap dan mampu melaksanakan Kurikulum 2013. Hal ini dibuktikan dengan masih banyaknya sekolah yang belum mampu memenuhi kebutuhan sarana dan prasarana pendukung untuk dapat menerapkan Kurikulum 2013 dan mencapai tujuan Kurikulum 2013 di sekolah masing-masing. Pemenuhan sarana dan prasarana pendukung tersebut menjadi salah satu kendala dalam implementasi Kurikulum 2013. Kepala Seksi Kurikulum Dinas Pendidikan Kota Yogyakarta (29 Desember 2014) memberikan keterangan yaitu jaringan internet wifi masih lemah, ketersediaan komputer di sekolah maupun laptop untuk masing-masing siswa masih terbatas, pemenuhan sarana ekstarkurikuler peminatan siswa terbatas, dan buku siswa dan buku guru belum terdistribusi maksimal. Pemenuhan sarana dan prasarana pendukung pembelajaran tersebut mempengaruhi pengembangan kompetensi dan minat siswa.

Kondisi nyata di lapangan yang menunjukkan bahwa Kurikulum 2013 belum dilaksanakan secara penuh sesuai standar. Salah satunya pada awal penerapan Kurikulum 2013 jenjang pendidikan di SMA dan SMK yang hanya menerapkan kurikulum baru untuk tiga mata pelajaran (mapel), yakni sejarah, matematika dan Bahasa Indonesia. Untuk mapel lain, guru direkomendasikan menggabungkan antara pendekatan lama dan baru. Situasi dan kondisi pembelajaran yang demikian seharusnya tidak dapat dilakukan karena pendidikan tidak dapat berjalan dengan dua buah sistem yang jauh berbeda. 
Dalam implementasi Kurikulum 2013, guru harus memahami bahwa tiap mata pelajaran mendukung semua kompetensi (sikap, pengetahuan, dan keterampilan) dan semua mata pelajaran diajarkan dengan pendekatan yang sama (saintifik) melalui mengamati, menanya, mencoba, mengolah, menyajikan, menyimpulkan, dan mencipta. Artinya, dalam Kurikulum 2013 tiap mata pelajaran mendukung semua kompetensi (sikap, ketrampilan, pengetahuan). Akan tetapi, pemahaman dan kompetensi guru untuk mengintegrasikan semua kompetensi dalam pembelajaran masih rendah. Dapat diketahui dari keterangan Kepala Seksi Kurikulum Dinas Pendidikan Kota Yogyakarta (5 Januari 2015) bahwa pelaksanaan pembelajaran di kelas masih sama dengan pembelajaran Kurikulum 2006. Guru belum menerapkan metode pembelajaran yang terintegrasi sesuai karakteristik Kurikulum 2013.

Hambatan lain yaitu masih adanya guru yang bingung dalam menerapkan Kurikulum 2013 terutama pada beberapa standar yang mengalami perubahan yaitu Standar Proses, Standar Isi, Standar Kompetensi Lulusan, dan Standar Penilaian. Pemahaman terhadap konten dan penerapan Kurikulum 2013 harus dipahami betul oleh sekolah terutama guru sebagai pelaksana pembelajaran di kelas. Guru merasa kesulitan dengan sistem penilaian pembelajaran siswa. Komponen penilaian yang cenderung bersifat deskriptif untuk setiap siswa dirasakan terlalu luas, sangat rinci, dan aspek-aspek penilaian sangat kompleks sehingga menyulitkan guru yang terbiasa dengan penilaian berupa angka. Dinas Pendidikan Pemuda dan Olahraga DIY sebagai lembaga yang memiliki tanggungjawab dalam terselenggaranya pendidikan harus terus mengupayakan untuk mengatasi berbagai permasalahan implementasi Kurikulum 2013 yang dihadapi sekolah, misalnya dengan melakukan pendampingan agar implementasi Kurikulum 2013 terselenggara dengan efektif.

Untuk melihat seberapa tinggi keefektifan implementasi Kurikulum 2013 pada sekolah-sekolah pilot project di wila- yah Kota Yogyakarta, maka diperlukan suatu evaluasi yang komprehensif terhadap implementasi Kurikulum 2013 tersebut. Sampai tahun kedua pelaksanaan Kurikulum 2013 bagi sekolah pilot project di Kota Yogyakarta, belum pernah dilakukan evaluasi tentang implementasi Kurikulum 2013. Secara umum, penelitian ini bertujuan untuk mengetahui ketercapaian tujuan dari pelaksananan Kurikulum 2013 di SMA yang ditunjuk sebagai pilot project di Kota Yogyakarta agar sesuai dengan apa yang telah dicita-citakan.

SMA yang merupakan sekolah pilot project Kurikulum 2013 di Kota Yogyakarta adalah SMA Negeri 1 Yogyakarta, SMA Negeri 2 Yogyakarta, SMA Negeri 3 Yogyakarta, SMA Negeri 8 Yogyakarta, SMA Muhammadiyah 1 Yogyakarta, dan SMA Muhammadiyah 2 Yogyakarta. Hingga dikeluarkannya kebijakan baru oleh Menteri Kebudayaan Pendidikan Dasar dan Menengah tentang penghapusan Kurikulum 2013 di seluruh sekolah di Indonesia, enam sekolah percontohan atau pilot project $\mathrm{Ku}$ rikulum 2013 di Kota Yogyakarta masih tetap menerapkan Kurikulum 2013 dengan segala keterbatasannya. Oleh karena itu, perlu adanya evaluasi tentang keefektifan implementasi Kurikulum 2013 pada SMA sebagai pilot project di Kota Yogyakarta sehingga sekolah dapat mengambil keputusan tentang keberlanjutan Kurikulum 2013.

Penelitian evaluasi ini dibatasi pada evaluasi implementasi Kurikulum 2013 pada SMA pilot project atau SMA percontohan Kurikulum 2013 di Kota Yogyakarta tahun ajaran 2013/2014 - 2014/2015. Evaluasi implementasi yang dilakukan di sekolah dibatasi pada komponen pelaksana kurikulum yaitu guru sebagai tenaga pendidik dalam implementasi Kurikulum 2013. Penelitian evaluasi ini bertujuan untuk mengevaluasi keefektifan implementasi Kurikulum 2013 pada SMA pilot project di Kota Yogyakarta dan mengetahui hambatan yang dihadapi dalam implementasi Kurikulum 2013 pada SMA pilot project di Kota Yogyakarta. 
Hasil penelitian ini diharapkan dapat memberikan sumbangan pemikiran dalam proses evaluasi implementasi Kurikulum 2013 dan dapat dijadikan rujukan untuk penelitian lebih lanjut tentang evaluasi implementasi Kurikulum 2013. Selain itu, menjadi sumber informasi dalam meningkatkan kualitas pembelajaran menggunakan Kurikulum 2013 bagi guru, memberikan sumbangan konsep pengembangan pembelajaran dengan Kurikulum 2013 bagi pengelola Kurikulum 2013, dan sebagai acuan yang dapat dipertimbangkan dalam pengambilan keputusan mengenai kelanjutan dari penerapan Kurikulum 2013 bagi pusat pengembangan kurikulum.

Setiap bagian dalam pendidikan hendaklah diatur dengan manajemen yang baik termasuk dalam implementasi kurikulum. Dengan sebuah manajemen yang baik, semua perangkat pendidikan akan bersinergi dengan baik sehingga dapat mencapai tujuan. Tim Dosen Administrasi Pendidikan Universitas Pendidikan Indonesia $(2013$, p. 86$)$ menyatakan bahwa, manajemen merupakan suatu proses tertentu yang menggunakan kemampuan atau keahlian untuk mencapai suatu tujuan yang didalam pelaksanaannya dapat mengikuti alur keilmuan secara ilmiah dan dapat pula menonjolkan kekhasan atau gaya manajer dalam mendayagunakan kemampuan orang lain. Sedangkan kurikulum dapat didefinisikan Kennedy (Grossman, Lee, \& Kennedy, 2008, p. 3) sebagai (1) Curriculum as a prescribed plan for learning; (2) Curriculum as all the learning experiences encountered at school, planned and unplanned; (3) Curriculum as a reflection of the expectations that society has for young people; and (4) curriculum as a statements of values.

Sukmadinata (2002, p. 27) menjelaskan secara lebih rinci mengenai tiga konsep kurikulum. Pertama, kurikulum sebagai suatu substansi, yakni sebagai suatu rencana kegiatan belajar bagi siswa di sekolah, atau sebagai suatu perangkat tujuan yang ingin dicapai. Kurikulum juga dapat menunjuk kepada suatu dokumen tertulis yang berisi rumusan tentang tujuan, bahan ajar, kegiatan belajar mengajar, jadwal, dan evaluasi.
.... Kedua, kurikulum sebagai suatu sistem, yaitu sistem kurkulum mencakup struktur personalia, dan prosedur kerja bagaimana cara menyusun suatu kurikulum, melaksanakan, mengevaluasi, dan menyempurnakannya. ... Ketiga, kurikulum sebagai suatu bidang studi, yaitu bidang studi kurikulum yang bertujuan untuk mengembangkan ilmu tentang kurikulum dan sistem kurikulum.

Keberhasilan kurikulum melibatkan adanya perencanaan sampai dengan pengawasan, bahkan termasuk monitoring dan evaluasi. Oleh karena itu, ilmu manajemen harus menjadi landasan pokok dalam pelaksanaan kurikulum. Menurut Rusman (2012, p. 3) manajemen kurikulum adalah sebagai suatu sistem pengelolaan kurikulum yang kooperatif, komprehensif, sistemik, dan sistematik dalam rangka mewujudkan ketercapaian tujuan kurikulum.

Pada dasarnya, pelaksanaaan kurikulum di tingkat satuan pendidikan (sekolah) lebih mengutamakan untuk merealisasikan dan merelevansikan antara kurikulum yang berlaku menurut standar nasional dengan kondisi daerah atau sekolah masing-masing. Oleh karena itu, pengelolaannya disesuaikan dengan kebutuhan, situasi, dan kondisi di sekolah. Tatanan manajemen kurikulum tersebut dipengaruhi pula oleh perubahan sosial politik dan budaya Indonesia. Pengaruh langsung diterima terutama pada implementasi kurikulum sebagai salah satu fungsi manajemen kurikulum. Menurut Mulyasa (2014, p. 26), bahwa pelaksanaan atau sering disebut implementasi adalah proses yang memberikan kepastian bahwa pembelajaran telah memiliki sumber daya manusia dan sarana prasarana yang diperlukan, sehingga dapat membentuk kompetensi, karakter dan mencapai tujuan yang diinginkan.

Mars (Rusman, 2012, p. 74) mengatakan bahwa, terdapat lima elemen yang mempengaruhi implementasi kurikulum yaitu dukungan dari kepala sekolah, dukungan dari rekan sejawat guru, dukungan dari siswa, dukungan dari orang tua, dan dukungan dari dalam diri guru adalah unsur yang utama. 
Dari lima elemen yang memengaruhi implementasi kurikulum, yang paling memiliki peran adalah guru. Brand (Mulyasa, 2008 , p. 9) menyatakan bahwa hampir semua usaha reformasi pendidikan seperti pembaharuan kurikulum dan penerapan metode pembelajaran, semuanya bergantung kepada guru. Brady \& Kennedy (2010, p. 6) juga menyebutkan usaha guru dalam implementasi kurikulum, yaitu ....teachers simply implement the curriculum guidelines that govern the school. Yet more importanly, they interpret those guidelines and add a pedagogical dimension that creates day-to-day curriculum experiences for students. Teachers, in reality, are the mediators of the curriculum.

Fitzpatrick, Sanders, \& Worthen (2011, p. 7) mengatakan bahwa, evaluation as the importance of evaluation criteria: it is the identification, clarification, and application of defensible criteria to determine an evaluation object's value (worth or merit) in relation to those criteria. Menurut Rusman (2012, pp. 94-95) proses evaluasi kurikulum berlangsung secara bertahap dan berjenjang, yaitu: (1) proses analisis kebutuhan dan kelayakan sebagai langkah awal untuk mendesain kurikulum, (2) proses perencanaan dan pengembangan suatu kurikulum sesuai dengan kebutuhan suatu lembaga pendidikan, (3) proses implementasi/pelaksanaan kurikulum yang berlangsung dalam suatu proses pembelajaran, (4) proses evaluasi kurikulum untuk mengetahui tentang tingkat keberhasilan kurikulum, (5) proses perbaikan kurikulum berdasarkan hasil evaluasi terhadap keterlaksanaan dan kelemahannya setelah dilakukan penialaian kurikulum, dan (6) proses penelitian evaluasi kurikulum, dalam hal ini erat kaitannya dengan tahap-tahap proses lainnya, tetapi lebih mengarah pada pengembangan kurikulum sebagai cabang ilmu dan teknologi.

Secara umum tujuan evaluasi mengacu pada upaya pengumpulan, pengelolaan, dan penyajian data sebagai masukan dalam mengambil keputusan. Kaufman \& Thomas (1980, p. 5) menyebutkan bahwa tujuan evaluasi adalah to collect data (result), convert the data into information (that which aids in making a useful decision) and use the information to make decisions. If decisions are not made, the evaluation might just as well have been skipped.

Dijelaskan oleh Kaufman \& Thomas, bahwa tujuan evaluasi untuk mengumpulkan data ke dalam informasi, untuk digunakan sebagai rekomendasi kepada para pengambil keputusan dalam menentukan tindak lanjut program, apakah program akan diteruskan, direvisi atau dihentikan. Kaufman \& Thomas (1980, pp. 109-110) menyebutkan ada delapan model evaluasi program, yaitu: Scriven's Formative-summative Model, CIPP, CSE-UCLA, Stake's Countenance, Tyler's Goal Attainment, Provus's Discrepancy, Scriven's Goal-Free, dan Stake's Responsive Model.

Menurut Peraturan Pemerintah No. 32 Tahun 2013, Standar Nasional Pendidikan (SNP) (Republik Indonesia, 2013) adalah kriteria minimal tentang sistem pendidikan di seluruh wilayah hukum Negara Kesatuan Republik Indonesia. SNP dalam Badan Standar Nasional Pendidikan (BSNP). Perubahan yang terjadi dalam Kurikulum 2006 menjadi Kurikulum 2013 membawa pula pergeseran elemen-elemen utama berdasarkan pendekatan-pendekatan pembelajaran, yaitu elemen-elemen khusus perubahan Kurikulum 2013 dalam pedoman pelatihan Kurikulum 2013 (Kemdikbud, 2014) yang mencakup Standar Kompetensi Lulusan (SKL), Standar Isi (SI), Standar Proses, dan Standar Penilaian.

Kurikulum 2013 merupakan langkah lanjutan pengembangan Kurikulum Berbasis Kompetensi (KBK) yang telah dirintis pada tahun 2004 dan KTSP 2006. Kurikulum 2013 mencakup kompetensi sikap, pengetahuan, dan ketrampilan secara terpadu.

Mulyasa (2014, p. 12) menjelaskan bahwa Kurikulum 2013 lebih fokus dan berangkat dari karakter serta kompetensi yang akan dibentuk, baru memikirkan untuk mengembangkan tujuan yang akan dicapai. Semua komponen lebih diarahkan pada pembentukan karakter dan kompetensi peserta didik yang diharapkan, baik dalam jangka pendek maupun jangka panjang. Dalam hal ini semakin banyak pihak 
yang terlibat dalam pembentukan karakter dan kompetensi, akan semakin efektif hasil yang diperoleh. Oleh karena itu, untuk mengefektifkan program pendidikan karakter dan meningkatkan kompetensi dalam Kurikulum 2013 diperlukan koordinasi, komunikasi, dan jalinan kerja sama antara sekolah, orang tua, masyarakat, dan pemerintah baik dalam perencanaan, pelaksanaan, maupun evaluasi dan ingindalian. Kemdikbud (2014, pp. 2-3) menyatakan bahwa tujuan yang harus dicapai dalam implementasi Kurikulum 2013 adalah: (1) memenuhi 8 (delapan) Standar Nasional Pendidikan; (2) manghadapi tantangan masa depan antara lain globalisasi, kemajuan teknologi informasi; (3) menguasai kompetensi masa depan antara lain kemampuan berkomunikasi, berpikir jernih dan kritis, bertanggungjawab, toleran dengan perbedaan, dan kesiapan untuk bekerja, (4) memahami persepsi masyarakat yang terlalu menitikberatkan pada aspek kognitif, beban kepada siswa, kurang bermuatan karakter, (5) mengembangkan pengetahuan dan pedagogi, (6) memahami peserta didik, (7) menyempurnakan pola pikir pendidikan sesuai dengan kebutuhan masa depan, dan (8) mampu melakukan penguatan tata kelola kurikulum melalui penetapan kompetensi, kerangka dasar, dan struktur kurikulum.

Implementasi Kurikulum 2013 diharapkan dapat menghasilkan insan yang produktif, kreatif, dan inovatif. Mulyasa (2014, pp. 163-164) mengatakan bahwa hal ini dimungkinkan, karena Kurikulum ini berbasis karakter dan kompetensi, yang secara konseptual memiliki beberapa keunggulan yaitu: (1) Kurikulum 2013 menggunakan pendekatan yang bersifat alamiah (kontekstual), karena berangkat, berfokus, dan bermuara pada hakekat peserta didik untuk mengembangkan berbagai kompetensi sesuai dengan potensinya masingmasing. Dalam hal ini peserta didik merupakan subjek belajar, dan proses belajar berlangsung secara alamiah dalam bentuk bekerja dan mengalami berdasarkan kompetensi tertentu, bukan transfer pengetahuan (transfer knowledge), (2) Kurikulum 2013 yang berbasis karakter dan kompetensi mendasari pengembangan kemampuan-kemampuan lain. Penguasaan ilmu pengetahuan, keahlian tertentu dalam suatu pekerjaan, kemampuan memecahkan masalah dalam kehidupan sehari-hari, serta pengembangan aspek-aspek kepribadian dapat dilakukan secara optimal berdasarkan standar kompetensi tertentu, dan (3) ada bidang-bidang studi atau mata pelajaran tertentu yang dalam pengembangannya lebih tepat mengunakan pendekatan kompetensi, terutama yang berkaitan dengan ketrampilan.

(Muhaimin, 2004, pp. 191-192) menjelaskan kriteria-kriteria evaluasi program pendidikan sesuai kriteria evaluasi kurikulum secara internal-eksternal dapat disusun beberapa kriteria suatu disain instruksional kurikulum, yaitu: (1) ketepatan unsur-unsur pembelajaran, (2) kesesuaian antara topik dengan pembelajaran siswa, (3) kesesuaian sumber daya dengan kebutuhan pembelajaran, (4) kemampuan pengembangan program, (5) kesesuaian antara kebijakan program dengan pelaksanaan, (6) efisiensi komponen program, (7) hasil pelaksanaan program, (8) dampak yang diperoleh dari pelaksanaan program.

\section{Metode Penelitian}

Jenis penelitian yang digunakan dalam penelitian ini adalah penelitian evaluasi dengan pendekatan kuantitatif. Model evaluasi yang digunakan adalah Provus Discrepancy Evaluation Model. Model evaluasi kesenjangan ini dikembangkan oleh Malcolm Provus. Model discrepancy evaluation atau evaluasi kesenjangan membandingkan antara tujuan atau standar dengan hasil pelaksanaan sesungguhnya, yang difokuskan pada implementasi Kurikulum 2013 pada sekolah pilot project.

Penelitian evaluasi ini dilakukan di SMA di Kota Yogyakarta yang menjadi sekolah pilot project Kurikulum 2013. Sekolah-sekolah tersebut adalah SMA Negeri 1 Yogyakarta, SMA Negeri 2 Yogyakarta, SMA Negeri 3 Yogyakarta, SMA Negeri 8 Yogyakarta, SMA Muhammadiyah 1 Yog- 
yakarta dan SMA Muhammadiyah 2 Yogyakarta. Studi pendahuluan penelitian evaluasi ini dilakukan pada bulan Desember 2014 sampai dengan bulan Januari 2015. Sedangkan, penelitian evaluasi impelementasi Kurikulum 2013 dilakukan pada bulan Februari 2015 sampai dengan April 2015.

Populasi penelitian evaluasi ini adalah seluruh guru SMA pilot project Kurikulum 2013 di Kota Yogyakarta. Jumlah populasi adalah 406 responden. Teknik sampling yang digunakan adalah sampling puposive. Sampel penelitian ditentukan dengan cara melihat tabel Krejcie dan Morgan dengan taraf kesalahan 5\% sehingga diambil sampel 200 responden.

Teknik pengumpulan data yang digunakan dalam penelitian ini adalah teknik angket/kuesioner dan dokumentasi. Tujuan penggunaan teknik tersebut adalah untuk memperoleh informasi yang relevan dengan tujuan penelitian dan memiliki validitas. Angket dalam penelitian ini merupakan angket tertutup, yaitu pernyataan yang dituliskan telah disediakan jawaban pilihan, sehingga responden dapat memilih salah satu jawaban. Jadi, jawabannya adalah terikat. Angket penelitian ini menggunakan skala dua yaitu skala pengukuran dengan jawaban tegas "ya/sesuai-tidak sesuai" dibuat dalam bentuk checklist. Teknik pengumpulan data dokumentasi digunakan sebagai salah satu teknik mengumpulkan data yang sumber datanya berupa paper yang berkaitan dengan implementasi Kurikulum 2013. Adapun jenis data tersebut adalah: (a) profil sekolah; (b) kalender akademik; (c) data guru; dan (d) struktur kurikulum.

Instrumen pengumpulan data evaluasi implementasi Kurikulum 2013 yang digunakan adalah lembar angket. Penyusunan instrumen berupa angket berpedoman pada kajian teori yang kemudian dijabarkan menjadi indikator penyusunan untuk membuat butir pernyataan.

Pengujian validitas instrumen dilakukan dengan dua cara, yakni dengan validasi ahli (face validity atau expert judgment) dan dengan validitas isi (content validity).
Dalam menguji validitas isi menggunakan validitas logis yaitu mengkonsultasikan butir-butir instrumen kepada ahli (experts judgment) kepada dosen ahli. Instrumen diujicobakan untuk mendapatkan validitas empiris kepada 30 responden.

Penghitungan uji validitas instrumen yang akan digunakan adalah Product moment. Data ujicoba diolah dengan bantuan program komputer SPSS versi 17.0. Berdasarkan tabel bahwa nilai corrected item total correlation merupakan $\mathrm{r}$ hitung product momment. Dari dengan $n=30$ maka $r$ hitung dibandingkan dengan $r$ tabel sebesar 0,361 untuk melihat kriteria validitas. Hasil uji validitas instrumen pada kolom/item Corrected Item-Total Correlation, ternyata dari 118 butir pertanyaan/pernyataan terdapat 17 butir yang tidak valid karena angka yang dihasilkan lebih kecil dari 0,361.

Penghitungan koefisien reliabilitas instrumen menggunakan Kuder-Richardson (KR.20) karena butir soal yang dinilai berupa jawaban tegas "ya/sesuai dan tidak/tidak sesuai". Uji reliabilitas instrumen menggunakan rumus Kuder-Richardson (KR20), melalui bantuan software Excel dapat diketahui hasil uji reliabilitas instrumen kepada 30 responden, varians total sebesar 391,1123 dan koefisien korelasinya sebesar 0,9675. Hasil penghitungan menunjukkan bahwa nilai koefisien korelasi $0,9675 \geq \mathbf{0 , 6}$ dan nilainya mendekati $\mathbf{1}$, dengan demikian instrumen dinyatakan reliabel.

Dalam penelitian ini data yang diperoleh dianalisis dengan teknik persentase. Adapun langkah-langkah dalam memberikan nilai dilakukan dengan cara: (1) memberikan penilaian terhadap setiap ketercapaian indikator pelaksanaan program dengan memberikan skor 1 (satu) untuk setiap skor yang dilaksanakan, skor 0 (nol) untuk indikator pelaksanaan program yang tidak dilaksanakan, dan (2) Menghitung persentase ketercapaian dengan menjumlahkan kinerja yang dilaksanakan, kemudian dibagi dengan jumlah seluruh kriteria pelaksanaan program sesuai dengan standarnya, kemudian dikalikan 100. 
Setelah data terkumpul selanjutnya dilakukan analisis dengan langkah-langkah yang terdiri dari: (a) mengorganisasi data, (b) menentukan teknik analisis data, (c) mengungkap kondisi variabel, (d) mengambil kesimpulan. Mengorganisasi data meliputi memilih, memilah, dan menata dengan memasukkan data dalam bentuk tabel, diagram/grafik. Data yang diberikan pada responden dengan metode angket kemudian dianalisis.

Kriteria keberhasilan evaluasi yang digunakan untuk mengevaluasi implementasi Kurikulum 2013 adalah sintesa yang memadukan teori kriteria-kriteria evaluasi program pendidikan yang diungkapkan oleh Muhaimin dengan mengacu pada tujuan implementasi Kurikulum 2013 oleh Kemdikbud 2014

Oleh karena data yang diperoleh dari angket adalah data kuantitatif, maka perlu dikonversikan ke data kualitatif skala lima. Untuk mengetahui data hasil konversi tersebut digunakan penentuan interval skor konversi data kuantitatif ke kualitatif seperti Tabel 1.

Tabel 1. Konversi Data Kuantitatif ke Data Kualitatif dengan Skala Lima (Sukarjo, 2006, p. 55)

\begin{tabular}{ccc}
\hline Nilai & Interval Skor & Data Kualitatif \\
\hline A & $\mathrm{X}>\overline{\mathrm{X}}+1,80 \mathrm{SB}$ & Sangat Efektif \\
B & $\overline{\mathrm{X}}+0,60 \mathrm{SB}<\mathrm{X} \leq \overline{\mathrm{X}}+1,80 \mathrm{SB}$ & Efektif \\
C & $\overline{\mathrm{X}}-0,60 \mathrm{SB}<\mathrm{X} \leq \overline{\mathrm{X}}+0,60 \mathrm{SB}$ & Cukup \\
D & $\bar{X}-1,80 \mathrm{SB}<\mathrm{X} \leq \bar{X}-0,60 \mathrm{SB}$ & Kurang \\
E & $\mathrm{X} \leq \bar{X}-1,80 \mathrm{SB}$ & Sangat kurang \\
\hline
\end{tabular}

Keterangan:

$\bar{X} \quad:$ Rerata skor ideal $=1 / 2$ (skor maksimal ideal + skor minimal ideal)

$S B$ : Simpangan baku skor ideal $=1 / 6$ (skor maksimal ideal - skor minimal ideal)

$X \quad$ :Skor aktual

\section{Hasil Penelitian dan Pembahasan}

Hasil penelitian mencakup komponen yang berkaitan dengan implementasi Kurikulum 2013 di SMA pilot project Kota
Yogyakarta. Komponen tersebut adalah ketercapaian pemahaman tujuan, kompetensi, metode pembelajaran Kurikulum 2013, motivasi guru dalam implementasi Kurikulum 2013, dan hambatan implementasi Kurikulum 2013. Capaian implementasi Kurikulum 2013 di SMA pilot project Kota Yogyakarta berdasarkan komponen evaluasi implementasi Kurikulum 2013 seperti pada Tabel 2.

Tabel 2. Capaian Implementasi Kurikulum 2013 di SMA Pilot Project Kota Yogyakarta Berdasar Komponen Evaluasi Implementasi Kurikulum 2013

\begin{tabular}{cccc}
\hline No & Komponen & $\begin{array}{c}\text { Skor } \\
\text { Capai- } \\
\text { an (\%) }\end{array}$ & $\begin{array}{c}\text { Kesen- } \\
\text { jangan }\end{array}$ \\
\hline 1 Ketercapaian tujuan & & \\
& $\begin{array}{l}\text { a. Pemahaman ketercapaian } \\
\text { tujuan implementasi } \\
\quad \begin{array}{l}\text { Kurikulum 2013 } \\
\text { Rata-rata }\end{array}\end{array}$ & 94,72 & 5,293 \\
& $\mathbf{9 4 , 7 2}$ & $\mathbf{5 , 2 9 3}$
\end{tabular}

2 Kompetensi

a. Penguasaan Kurikulum $2013 \quad 90,58 \quad 9,419$

b. Penguasaaan manajemen $\quad 87,56 \quad 12,439$ kelas dalam pembelajaran Kurikulum 2013

c. Pemahaman terhadap peserta $\quad 91,74 \quad 8,26$ didik

d. Kemampuan mengevaluasi $\quad 85,39 \quad 14,673$

e. Kemampuan $\quad 94,83 \quad 5,171$ mengembangkan potensi

$\begin{array}{lll}\text { Rata-rata } \quad 90,02 & 9,99\end{array}$

3 Metode pembelajaran Kurikulum 2013

a. Metode pembelajaran $\quad 68,44 \quad 31,56$

b. Sumber belajar $\quad 92,14 \quad 7,86$

$\begin{array}{lll}\text { Rata-rata } \quad 80,29 & 19,71\end{array}$

4 Motivasi guru dalam implementasi Kurikulum 2013

a. Pemahaman kebutuhan $95 \quad 5,005$

b. Ketrampilan $\quad 92,08 \quad 7,992$

c. Dukungan implementator lain $86,24 \quad 13,762$

$\begin{array}{lll}\text { Rata-rata } \quad 91,1 & 8,9\end{array}$

5 Hambatan

a. Hambatan yang dialami guru $\quad 70,61 \quad 29,392$ dalam implementasi

Kurikulum 2013

\begin{tabular}{ccc} 
Rata-rata & 70,61 & 29,392 \\
Rata-rata Total & 87,444 & 12,563 \\
Standar Deviasi & 8,97814 \\
\hline
\end{tabular}

Rekapitulasi tersebut dapat dilihat dalam diagram pada Gambar 1. 


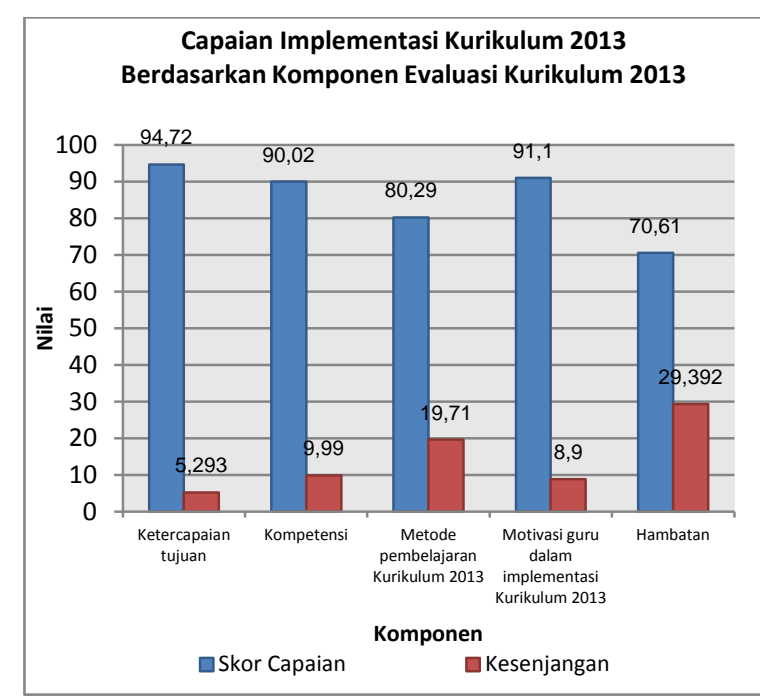

Gambar 1. Diagram Capaian Implementasi Kurikulum 2013 Berdasarkan Komponen Evaluasi Kurikulum 2013 di SMA Pilot Project Kota Yogyakarta

Hasil analisis untuk masing-masing komponen dapat dideskripsikan, yaitu: (1) ketercapaian tujuan implementasi Kurikulum 2013 di SMA pilot project Kota Yogyakarta rata-ratanya adalah $94,72 \%$ dengan rata-rata kesenjangan (discrepancy) 5,293\%. Skor menunjukkan bahwa kriteria keefektifan "Sangat Efektif"; (2) pencapaian kompetensi yang dimilki guru rata-ratanya adalah 90,02\% dengan rata-rata kesenjangan (discrepancy) 9,99\%. Skor tersebut tercapai dengan kriteria "Sangat Efektif"; (3) metode pembelajaran Kurikulum 2013 rataratanya adalah $80,29 \%$ dengan rata-rata kesenjangan (discrepancy) 19,71\% dan menunjukkan hasil "Efektif"; (4) motivasi guru dalam implementasi Kurikulum 2013 ber- dasarkan hasil deskripsi data hasil penelitian menunjukkan capaian rata-rata $91,10 \%$ dengan rata-rata kesenjangan (discrepancy) $8,90 \%$. Besarnya motivasi digolongkan ke dalam kriteria efektivitas "Sangat Efektif"; (5) komponen hambatan tersebut memiliki skor rata-rata $70,61 \%$ dengan rata-rata kesenjangan (discrepancy) 29,39\% dengan kriteria keefektifan "Cukup (C)".

Setelah melihat rekapitulasi capaian hasil implementasi Kurikulum 2013 di SMA pilot project Kota Yogyakarta berdasarkan keseluruhan komponen evaluasi implementasi Kurikulum 2013 menunjukkan bahwa capaian rata-ratanya adalah $87,444 \%$ dengan rata-rata kesenjangan (discrepancy) $12,563 \%$ dengan standar deviasi 8,97814. Capaian hasil implementasi Kurikulum 2013 di SMA pilot project Kota Yogyakarta berdasarkan keseluruhan komponen evaluasi implementasi Kurikulum 2013 tersebut menunjukkan kriteria "Efektif". Dari lima komponen dapat diketahui bahwa komponen yang memiliki capaian rata-rata paling tinggi adalah komponen ketercapaian tujuan yang memiliki rata-rata capaian adalah $94,724 \%$ dengan rata-rata kesenjangan (discrepancy) 5,293\%. Sedangkan komponen yang memiliki capaian rata-rata paling rendah adalah komponen hambatan yang memiliki rata-rata capaian $70,61 \%$ dengan rata-rata kesenjangan (discrepancy) 29,392\%.

Jika dibandingkan hasil capaian skor implementasi Kurikulum 2013 di SMA pilot project Kurikulum 2013 Kota Yogyakarta dapat dilihat pada Tabel 3.

Tabel 3. Perbandingan Capaian Skor Implementasi Kurikulum 2013 di SMA Pilot Project Kurikulum 2013 Kota Yogyakarta

\begin{tabular}{lcccccc}
\hline Nama & $\begin{array}{c}\text { SMA N 1 } \\
\text { Yogyakarta }\end{array}$ & $\begin{array}{c}\text { SMA N 2 } \\
\text { Yogyakarta }\end{array}$ & $\begin{array}{c}\text { SMA N 3 } \\
\text { Yogyakarta }\end{array}$ & $\begin{array}{c}\text { SMA Negeri 8 } \\
\text { Yogyakarta }\end{array}$ & $\begin{array}{c}\text { SMA Muh. 1 } \\
\text { Yogyakarta }\end{array}$ & $\begin{array}{c}\text { SMA Muh. 2 } \\
\text { Yogyakarta }\end{array}$ \\
\hline Total Capaian & 1055,4 & 1099,94 & 1018 & 1056 & 1014 & 1053 \\
Rata-rata Capaian & 87,95 & 91,66 & 84,81 & 87,97 & 84,48 & 87,75 \\
Total Kesenjangan & 144,6 & 100,065 & 182,3 & 144,3 & 186,2 & 148 \\
Rata-rata Kesenjangan & 12,05 & 8,339 & 15,19 & 12,03 & 15,52 & 12,25 \\
SD Capaian & 8,874 & 7,931 & 13,18 & 10,58 & 10,66 & 7,069 \\
SD Kesenjangan & 8,874 & 7,931 & 13,18 & 10,58 & 10,66 & 7,069 \\
Kriteria Efektivitas & Efektif & Sangat & Efektif & Efektif & Efektif & Efektif \\
Peringkat & III & I & V & II & VI & IV \\
\hline
\end{tabular}


Berdasarkan analisis hasil pada setiap sekolah tersebut diketahui bahwa capaian skor yang paling tinggi adalah SMA Negeri 2 Yogyakarta dengan rata-ratanya 91,66\% dengan rata-rata kesenjangan (discrepancy) 8,339\%. Capaian skor yang paling rendah adalah SMA Muhammadiyah 1 Yogyakarta dengan rata-ratanya $84,48 \%$ dengan rata-rata kesenjangan (discrepancy) $15,52 \%$.

Efektivitas Pemahaman Tujuan Implementasi Kurikulum 2013

Pemahaman tujuan menjadi hal yang penting sebagai arah atau petunjuk terhadap sesuatu yang akan dicapai. Jika dihubungkan dengan literatur di bab II, terdapat kesesuaian antara pentingnya tujuan dalam pembelajaran yang merupakan salah satu hal yang mempengaruhi keberhasilan implementasi kurikulum. Hamalik (2011) berpendapat bahwa "tujuan memiliki nilai yang sangat penting di dalam pengajaran. Bahkan dapat dikatakan bahwa tujuan merupakan faktor yang terpenting dalam kegiatan dan proses belajar mengajar".

Komponen ketercapaian tujuan dapat dilihat dari hasil skor capaian guru memahami pelaksanaan Kurikulum 2013 sebagai lanjutan langkah perbaikan Kurikulum 2006 dan butir capaian guru melaksanakan Kurikulum 2013 atas dasar Standar Nasional Pendidikan yang mendapatkan skor rata-rata tertinggi yaitu $97 \%$ dengan ratarata kesenjangan (discrepancy) masing-masing 3\%. Skor capaian tersebut menunjukkan bahwa guru telah mencapai kriteria "sangat efektif" dalam memahami pentingnya pemahaman tujuan implementasi Kurikulum 2013 dan melaksanakannya sesuai dengan perubahan dan perbaikan atas dasar Standar Nasional Pendidikan. Guru menyadari bahwa dalam ketercapaian tujuan implementasi Kurikulum 2013 perlu perubahan pola pikir berkaitan dengan perubahan elemen-elemen standar yaitu Standar Kompetensi Lulusan, Standar Isi, Standar Proses, dan Standar Penilaian.

Ketercapaian tujuan implementasi Kurikulum 2013 dapat dipengaruhi oleh perubahan pola pikir guru agar guru menyadari, memahami, dan memiliki komitmen yang tinggi untuk menyukseskan implementasi Kurikulum 2013 dengan sepenuh hati. Perubahan pola pikir atau mindset ini sejalan dengan pendapat Mulyasa, (2014b, p. 46) bahwa "mengubah mindset dalam penataan kurikulum dimaksudkan adalah mengubah pola pikir dan cara pandang guru, khususnya cara pandangnya terhadap pembelajaran dan peserta didik".

Efektivitas Kompetensi yang Dimiliki Guru dalam Implementasi Kurikulum 2013

Tuntutan guru sebagai tenaga pendidik untuk memiliki kompetensi khusus sebagaimana diuraikan mengharuskan guru memperkaya kompetensi yang mereka miliki. Guru dalam mengaktualisasi implementasi kurikulum menjadi praktik pembelajaran harus terlebih dahulu memahami struktur kurikulum yang berlaku di sekolah sehingga dalam praktik pembelajaran dapat berjalan dengan baik.

Secara umum, aspek yang paling tinggi dicapai oleh guru adalah pada aspek kelima yaitu aspek kemampuan mengembangkan kompetensi memiliki capaian yang paling tinggi yaitu $94,83 \%$ dengan rata-rata kesenjangan (discrepancy) 5,17\%. Dalam aspek ini guru dituntut untuk mampu membimbing siswa mengembangkan berpikir kreatif dan inovatif yang mendapatkan skor tertinggi yaitu memiliki rata-rata 95,5\% dengan rata-rata kesenjangan (discrepancy) $4,5 \%$. Skor capaian butir ini merupakan skor capaian tertinggi dalam komponen kompetensi guru. Skor capaian ini membuktikan bahwa guru di SMA pilot project Kurikulum 2013 Kota Yogyakarta telah mengaktualisasikan pemahaman terhadap tujuan dengan langkah nyata berupa kemampuan mengembangkan kompetensi terutama membimbing siswa mengembangkan berpikir kreatif dan inovatif.

Pencapaian kompetensi guru di SMA pilot project Kurikulum 2013 Kota Yogyakarta ini sesuai dengan tujuan Kurikulum 2013 yang diungkapkan oleh Mulyasa (2014, p. 65) yaitu "untuk menghasilkan insan Indonesia yang produktif, kreatif, 
inovatif, dan afektif melalui penguatan sikap, ketrampilan, dan pengetahuan yang terintegrasi". Bentuk dari kegiatan membimbing siswa mengembangkan berpikir kreatif dan inovatif salah satunya adalah dengan pembimbingan baik di dalam maupun di luar jam sekolah dengan materi dan waktu sesuai dengan kesepakatan guru dan siswa.

Efektivitas Metode Pembelajaran Kurikulum 2013

Efektivitas metode atau pendekatan pembelajaran yang diterapkan guru dapat dilihat dari seberapa efektif penerapan metode atau pendeketan pembelajaran tersebut menunjang keberhasilan pembelajaran Kurikulum 2013. Dalam pembelajaran Kurikulum 2013 guru dituntut untuk memahami dan menerapkan berbagai metode yang efektif untuk setiap materi pembelajaran. Diantaranya yaitu, pendekatan saintifik, pembelajaran berbasis proyek (Project based learning), pembelajaran berbasis masalah (Problem based learning), pembelajaran berbasis penemuan (Discovery learning), dan bagaimana kemampuan guru mengkombinasikan metode atau pendekatan pembelajaran tersebut.

Meskipun efektivitas komponen metode pembelajaran Kurikulum 2013 tersebut dikatakan efektif, tetapi jika dilihat pda aspek penyusunnya diketahui bahwa skor capaian pada aspek yang pertama yaitu metode pembelajaran rata-ratanya $68,44 \%$ dengan rata-rata kesenjangan (discrepancy) $31,56 \%$. Artinya ada $31,56 \%$ guru yang belum efektif menerapkan metode pembelajaran. Hal ini dapat dipengaruhi oleh kondisi siswa yang telah memiliki kesadaran yang tinggi dalam belajar. Siswa tidak lagi tergantung pada treatment yang diberikan guru. Siswa bertindak aktif dalam pembelajaran sehingga guru tidak lagi menjadi pusat pembelajaran.

Keaktifan siswa dituntut dalam pembelajaran terutama dalam pembelajaran berbasis penemuan (Discovery learning) ini. Oleh karena sekolah yang peneliti jadikan lokasi penelitian merupakan sekolah dengan jumlah rombongan belajar besar, ma- ka pembelajaran berbasis penemuan (Discovery learning) ini kurang efisien. Hal ini sesuai dengan beberapa kelemahan yang diungkapkan dari Kemdikbud (2014, p. 31) yaitu "... penerapan Discovery learning tidak efisien untuk mengajar jumlah siswa yang banyak, karena membutuhkan waktu yang lama untuk menemukan teori atau pemecahan masalah lainnya".

Besarnya Motivasi Guru dalam Implementasi Kurikulum 2013

Besarnya motivasi guru dalam implementasi Kurikulum 2013, dapat dilihat dari aspek pemahaman kebutuhan yang menunjukkan skor capaian paling tinggi yaitu $95,00 \%$ dengan rata-rata kesenjangan (discrepancy) 5,00\%. Skor capaian ini menunjukkan bahwa 95\% guru telah memahami kebutuhan siswa terutama kebutuhan kognitif. Pmahaman kebutuhan belajar siswa dapat direlevensikan dengan teori yang motivasi kerja yang diungkapkan oleh Rivai \& Murni (2012, p. 727) bahwa, ketika seorang pemimpin memotivasi karyawannya agar mereka mereka mempunyai motivasi kerja yang baik, artinya pemimpin tersebut sedang berusaha menimbulkan kebutuhan tertentu pada diri karyawannya, agar tingkah laku mereka tertuju kepada tujuan yang dikehendaki oleh pimpinan.

Berdasarkan teori tersebut jika disesuaikan dengan kondisi guru dalam memahami kebutuhan, maka guru memotivasi siswa agar siswa mempunyai motivasi belajar yang baik. Artinya guru sedang berusaha menimbulkan kebutuhan tertentu pada diri siswa agar tingkah laku siswa tertuju kepada tujuan belajar. Jadi, dengan adanya motivasi dari guru secara tidak langsung guru memunculkan kebutuhan siswa yang berorientasi pada tujuan pembelajaran dalam Kurikulum 2013.

Hambatan bagi Guru dalam Implementasi Kurikulum 2013

Komponen hambatan bagi guru dalam implementasi Kurkulum 2013 di SMA pilot project Kota Yogyakarta mencakup berbagai kendala atau masalah yang di- 
alami guru sebagai implementator Kurikulum 2013.

Fakta yang diperoleh pada komponen hambatan yang paling sedikit adalah bahwa guru mengalami hambatan dalam hal kurangnya dukungan dari implementator lain yaitu pustakawan memiliki ratarata capaian tertinggi yaitu $85,5 \%$ dengan rata-rata kesenjangan (discrepancy) $14,5 \%$. Skor capaian ini menunjukkan bahwa 85,5\% guru di SMA pilot project Kurikulum 2013 Kota Yogayakarta telah didukung pustakawan dalam kegaiatan pembelajaran terutama dalam hal sumber belajar. Jadi, terbukti bahwa antara guru dan pustakawan terjalin komunikasi yang baik karena ada peran aktif dari guru untuk mengkomunikasikan kebutuhan sumber belajar yang relevan.

Butir capaian yang memiliki skor rata-rata paling rendah adalah guru dihadapkan pada masalah peserta didik yang komplek dengan segala latar belakang kognitif maupun kepribadian yaitu 46\% dengan rata-rata kesenjangan (discrepancy) $54 \%$. Jadi, dapat diketahui bahwa sebagian besar guru di SMA pilot project Kurikulum 2013 Kota Yogyakarta mengalami hambatan dalam menghadapi permasalahan peserta didik yang komplek dengan segala latar belakang kognitif maupun kepribadian tersebut.

Seperti yang diungkapkan oleh Hamalik (2011, pp. 100-101) bahwa "murid adalah pribadi yang kompleks" sehingga guru harus mengenal siswa-siswanya dengan maksud agar guru dapat membantu pembelajaran siswa secara efektif. Penting mengenal dan memahami latar belakang siswa dengan seksama agar guru dapat menentukan metode atau pendekatan pembelajaran yang sesuai hingga dapat mendiagnosis jika terdapat kesulitan. Dengan memahami latar belakang siswa yang kompleks, maka guru juga dapat menganalisis kesulitan-kesulitan belajar siswa, melayani perbedaan-perbedaan individu siswa, dan memberikan bimbingan belajar yang berkaitan dengan individu siswa.

Berdasarkan analisis hasil data penelitian secara umum di SMA pilot project Kota Yogyakarta menunjukkan bahwa capaian rata-rata adalah $87,444 \%$ dengan rata-rata kesenjangan (discrepancy) 12,563\% dengan standar deviasi 8,97814. Capaian hasil implementasi Kurikulum 2013 di SMA pilot project Kota Yogyakarta berdasarkan ke-seluruhan komponen evaluasi implementasi Kurikulum 2013 tersebut menunjukkan kriteria "Efektif".

Hasil penelitian yang menunjukkan bahwa implementasi Kurikulum 2013 di SMA pilot project Kota Yogyakarta termasuk kriteria efektif, namun masih terdapat berbagai keterbatasan dalam penelitian yaitu, (1) pengumpulan data terkait pemahaman guru dan kepala sekolah tentang Implementasi Kurikulum 2013 di SMA Pilot Project Kota Yogyakarta hanya diukur dengan menggunakan ang-ket. Dengan demikian skor yang diperoleh pada penelitian ini merupakan persepsi dari responden, (2) penelitian ini menggunakan model evaluatif yang dapat digeneralisasikan, tetapi hanya dapat digunakan untuk sekolah menengah atas lain yang karakteristiknya hampir sama dengan sekolah yang diteliti dalam hal ini adalah sekolah pilot project, dan (3) penyusunan instrumen yang mengungkapkan data pemahaman hanya diukur dengan angket skala "ya-tidak" sehingga menghasilkan data yang bias.

\section{Simpulan}

Berdasarkan pembahasan hasil penelitian yang disampaikan dapat ditarik simpulan sebagai berikut. Pertama, efektivitas ketercapaian pemahaman tujuan implementasi Kurikulum 2013 di SMA pilot project Kota Yogyakarta menunjukkan skor capaian 94,72\% dengan rata-rata kesenjangan (discrepancy) 5,293\%. Skor ini menunjukkan ketercapaian tujuan implementasi $\mathrm{Ku}$ rikulum 2013 di SMA pilot project Kota Yogyakarta melalui pemahaman guru telah dicapai dengan "Sangat Efektif". Kedua, efektivitas kompetensi yang dimiliki guru dalam implementasi Kurikulum 2013 di SMA pilot project Kota Yogyakarta menunjukkan kompetensi guru rata-ratanya adalah 90,02\% dengan rata-rata kesenjangan (discrepancy) 9,99\%. Pencapaian kompetensi 
tersebut dapat dikatakan telah "Sangat Efektif".

Ketiga, efektivitas metode pembelajaran Kurikulum 2013 yang diterapkan dalam implementasi Kurikulum 2013 di SMA pilot project Kota Yogyakarta menunjukkan rata-ratanya $80,29 \%$ dengan rata-rata kesenjangan (discrepancy) 19,71\%. Skor capaian efektivitas metode pembelajaran Kurikulum 2013 tersebut menunjukkan hasil "Efektif". Keempat, besarnya motivasi guru dalam implementasi Kurikulum 2013 di SMA pilot project Kota Yogyakarta menunjukkan capaian rata-rata $91,10 \%$ dengan rata-rata kesenjangan (discrepancy) 8,90\%. Besarnya motivasi guru tersebut termasuk ke dalam kriteria efektivitas "Sangat Efektif". Kelima, hambatan bagi guru dalam implementasi Kurikulum 2013 di SMA pilot project Kota Yogyakarta menunjukkan komponen hambatan tersebut memiliki capaian rata-rata $70,61 \%$ dengan rata-rata kesenjangan (discrepancy) 29,39\%. Hambatan bagi guru tersebut termasuk dalam kriteria "Cukup". Hambatan yang paling sedikit dilakukan guru adalah pada butir kurangnya dukungan dari implementator lain yaitu pustakawan memiliki rata-rata capaian tertinggi yaitu $85,5 \%$ dengan ratarata kesenjangan (discrepancy) 14,5\%. Sedangkan hambatan terbesar adalah pada butir guru dihadapkan pada masalah peserta didik yang komplek dengan segala latar belakang kognitif maupun kepribadian yaitu $46 \%$ dengan rata-rata kesenjangan (discrepancy) 54\%.

Adapun saran yang dapat dikemukakan antara lain: (1) bagi kepala sekolah, guru perlu diberikan motivasi berkesinambungan yang sistematis dalam implementasi Kurikulum 2013 di sekolah. Implementasi Kurikulum 2013 sebagai salah satu fungsi dari manajemen kurikulum merupakan bentuk dari aktualisasi dari kurikulum yang telah direncanakan, sehingga sekolah perlu menyusun program perencanaan yang sesuai dengan karakteristik sekolah masing-masing dan tidak hanya sekedar dokumen; (2) bagi guru, agar guru semakin menyadari perubahan zaman dan IPTEK sehingga mampu menyesuaikan pola pikir mereka terkait dengan elemen perubahan standar Kurikulum 2013. Guru perlu meningkatkan kemampuan dalam melakukan evaluasi penilaian pembelajaran Kurikulum 2013. Guru juga perlu mengenal lebih dalam tentang latar belakang siswa baik kognitif maupun kepribadian karena berpengaruh pada tugas guru dalam membimbing, mendidik, mengajar, dan menyiapkan metode atau pendekatan pembelajaran yang sesuai dengan siswa; dan (3) bagi peneliti selanjutnya, hasil penelitian ini diharapkan bisa membantu para peneliti selanjutnya terutama yang akan meneliti tentang implementasi Kurikulum 2013 di sekolah menengah.

\section{Daftar Pustaka}

Brady, L., \& Kennedy, K. (2010). Curriculum Construction (5th ed.). Frenchs Forest NSW: Pearson Australia.

Fitzpatrick, J. L., Sanders, J. R., \& Worthen, B. R. (2011). Program evaluation: alternative approaches and practical guidelines (4th ed.). Boston: Pearson Education.

Grossman, D. L., Lee, W. O., \& Kennedy, K. J. (2008). Citizenship curriculum in asia and the pacific. Hongkong: Springer.

Hamalik, O. (2011). Proses belajar mengajar. Jakarta: Bumi Aksara.

Kaufman, R., \& Thomas, S. (1980). Evaluation without fear. New York: New View Points.

Kemdikbud. (2014). Materi pelatihan guru implementasi Kurikulum 2013 tahun 2014. Jakarta: Kementrian Pendidikan dan Kebudayaan (Kemdikbud).

Muhaimin. (2004). Wacana pengembangan pendidikan islam. Surabaya: Pustaka Pelajar.

Mulyasa, E. (2008). Standar kompetensi dan sertifikasi guru. Bandung: PT Remaja Rosda Karya.

Mulyasa, E. (2014a). Guru dalam implementasi kurikulum 2013. Bandung: PT Remaja Rosda Karya. 
Mulyasa, E. (2014b). Pengembangan dan implementasi kurikulum 2013. Bandung: PT Remaja Rosda Karya.

Republik Indonesia. peraturan pemerintah republik Indonesia nomor 32 tahun 2013 tentang perubahan atas peraturan pemerintah nomor 19 tahun 2005 tentang standar nasional pendidikan (2013).

Rivai, V., \& Murni, S. (2012). Education management: analisis teori dan praktik. Jakarta: Rajawali Pers.

Rusman. (2012). Manajemen kurikulum.
Jakarta: Rajawali Pers.

Sukarjo. (2006). Kumpulan materi evaluasi pembelajaran. Yogayakarta: Jurusan Tekonologi Pembelajaran Program Pascasarjana UNY.

Sukmadinata, N. S. (2002). Pengembangan kurikulum teori dan praktek. Bandung: Remaja Rosdakarya.

Tim Dosen Administrasi Pendidikan Universitas Pendidikan Indonesia. (2013). Manajemen pendidikan. Bandung: Alfabeta. 